\title{
Muons Inc Master CRADA with Annex A for Magnetron Development
}

Cooperative Research and Development Agreement Final Report

\section{CRADA Number: FRA-2017-0026}

\section{Fermilab Technical Contact: Timergali Khabiboulline}

Summary Report

24 July 2019 


\section{NOTICE}

This report was prepared as an account of work sponsored by an agency of the United States government. Neither the United States government nor any agency thereof, nor any of their employees, makes any warranty, express or implied, or assumes any legal liability or responsibility for the accuracy, completeness, or usefulness of any information, apparatus, product, or process disclosed, or represents that its use would not infringe privately owned rights. Reference herein to any specific commercial product, process, or service by trade name, trademark, manufacturer, or otherwise does not necessarily constitute or imply its endorsement, recommendation, or favoring by the United States government or any agency thereof. The views and opinions of authors expressed herein do not necessarily state or reflect those of the United States government or any agency thereof.

Available electronically at http://www.osti.gov/bridge

Available for a processing fee to U.S. Department of Energy and its contractors, in paper, from:

U.S. Department of Energy Office of Scientific and Technical Information

P.O. Box 62

Oak Ridge, TN 37831-0062

phone: 865.576.8401

fax: 865.576 .5728

email: mailto:reports@adonis.osti.gov

Available for sale to the public, in paper, from:

U.S. Department of Commerce

National Technical Information Service

5285 Port Royal Road

Springfield, VA 22161

phone: 800.553 .6847

fax: 703.605 .6900

email: orders@ntis.fedworld.gov

online ordering: http://www.ntis.gov/ordering.htm 
In accordance with Requirements set forth in Article XII.A(2) of the CRADA document, this document is the final CRADA report, including a list of Subject Inventions, to be forwarded to the Office of Science and Technical Information as part of the commitment to the public to demonstrate results of federally funded research.

CRADA number: $\quad$ FRA-2017-0026

CRADA Title: $\quad$ Muons Inc Master CRADA with Annex A for Magnetron Development

Parties to the Agreement: Muons, Inc. and Fermi Research Alliance, LLC

\section{Abstract of CRADA work:}

Modern CW or pulsed superconducting accelerators of megawatts beams require efficient RF sources controllable in phase and power. It is desirable to have an individual RF power source with power up to hundreds of $\mathrm{kW}$ for each Superconductive RF (SRF) cavity. For pulsed accelerators the pulse duration in millisecond range is required. The efficiency of the traditional RF sources (klystrons, IOTs, solid-state amplifiers) in comparison to magnetrons is lower and the cost of unit of RF power is significantly higher. Typically, the cost of RF sources and their operation is a significant part of the total project cost and operation. The magnetron-based RF sources with a cost of power unit of 1-3 dollars per Watt would significantly reduce the capital and operation costs in comparison with the traditional RF sources. This arouses interest in magnetron RF sources for use in modern accelerators. A recently developed kinetic model describing the principle of magnetron operation and subsequent experiments resulted in an innovative technique producing the "stimulated" generation of magnetrons powered below the self-excitation threshold voltage. The magnetron operation in this regime is stable, low noise, controllable in phase and power, and provides higher efficiency than other types of RF power sources. It allows operation in CW and pulse modes (at large duty factor). For pulsed operation this technique does not require pulse modulators to form RF pulses. It also looks as a promising opportunity to extend magnetron life time.

\section{Summary of Research Results:}

An innovative technique was developed, allowing a pulsed RF generation of a magnetron without modulation of the cathode voltage, while the tube is powered below the self-excitation threshold. A pulsed resonant injected signal with power $\geq-11 \mathrm{~dB}$ of the magnetron nominal power is required for such operation. The technique was substantiated by the developed kinetic model of the magnetron operation representing the principle of RF coherent generation of the tube. Experiments with a $2.45 \mathrm{GHz}$ magnetron proved the developed technique. The CW magnetron operating in the "stimulated" mode has efficiency higher than for its operation in a "free run" or driven by small $(\leq-20 \mathrm{~dB})$ injected signal. The latter cases relate to the traditional regimes when the tube operates above the self-excitation threshold. The magnetrons powered below the self-excitation threshold and driven by the sufficient resonant signal provide higher conversion efficiency, significantly lower (by $\approx 20 \mathrm{~dB} / \mathrm{Hz}$ ) spectral power density of noise and significantly wider (up to hundreds of $\mathrm{kHz}$ ) the phase control bandwidth. The developed innovative mode of magnetron operation demonstrates properties attractive for superconducting $\mathrm{CW}$ and pulsed accelerators with megawatts beams. Performed estimates of the cathode sputtering in high power $\mathrm{CW}$ magnetrons support expectations for extended lifetime of the magnetrons applicable for modern accelerator projects. 
4 Final Report for CRADA FRA-2017-0026

$\underline{\text { Related Reports, Publications, and Presentations: }}$

Report: https://arxiv.org/ftp/arxiv/papers/1905/1905.04550.pdf

Subject Inventions listing:

None

Report Date: 7-24-19

Technical Contact at Fermilab: Timergali Khabiboulline

This document contains NO confidential, protectable or proprietary information. 